\title{
Korelaty osobowościowe
} i socjodemograficzne wypalenia zawodowego w grupie funkcjonariuszy straży pożarnej $z$ terenu województwa lubelskiego

\section{Personality and socio-demographic correlates of proffesional burnout in a group of firemen from the Lublin Province}

\author{
Agata Madej ${ }^{1, A-D \odot}$ \\ ${ }^{1}$ Instytut Medycyny Wsi, Lublin, Polska \\ A - Koncepcja i projekt badania, B - Gromadzenie i/lub zestawianie danych, C - Analiza i interpretacja danych, \\ $D$ - Napisanie artykułu, E - Krytyczne zrecenzowanie artykułu, F - Zatwierdzenie ostatecznej wersji artykułu
}

Madej A. Korelaty osobowościowe i socjodemograficzne wypalenia zawodowego w grupie funkcjonariuszy straży pożarnej z terenu województwa lubelskiego. Med Og Nauk Zdr. 2020; 26(1): 72-77. DOI: 10.26444/monz/115939

\begin{abstract}
Streszczenie
Wprowadzenie. Praca funkcjonariuszy straży pożarnej cechuje się wieloma niebezpieczeństwami. Wśród nich wymienia się działania akcyjne, mogące niejednokrotnie wpływać negatywnie na zdrowie, a nawet stanowić zagrożenia życia. Częste narażenie na wydarzenia obciążające emocjonalnie może prowadzić m.in. do wystąpienia symptomów wypalenia zawodowego.
\end{abstract}

Cel pracy. Celem artykułu jest przedstawienie związku między cechami osobowości, poczuciem własnej skuteczności i poziomem stresu a składowymi wypalenia zawodowego w grupie funkcjonariuszy straży pożarnej z terenu województwa lubelskiego.

Materiał i metody. W badaniu udział wzięło 120 strażaków w wieku 22-52 lata, pracujących w Biłgoraju i w Zamościu. Narzędzia badawcze stanowiły: ankieta socjodemograficzna własnego autorstwa, Skala Uogólnionej Własnej Skuteczności GSES, Skala Odczuwanego Stresu PSS-10, Inwentarz Osobowości NEO-FFI, Kwestionariusz Wypalenia Zawodowego Maslach MBI.

Wyniki. Analizy badań własnych potwierdziły istnienie związku między cechami osobowości, poziomem odczuwanego stresu i poczuciem własnej skuteczności a składowymi wypalenia zawodowego w grupie badanych funkcjonariuszy straży pożarnej. Wzrost poziomu sumienności warunkuje wzrost poczucia dokonań osobistych. Stres osiągnął istotność statystyczną jako predyktor wyczerpania emocjonalnego i depersonalizacji. Wraz z polepszeniem się sytuacji finansowej oraz jakości współpracy pomiędzy badanymi a przełożonymi/ kolegami z pracy rośnie poczucie skuteczności własnej oraz poziom osobistych dokonań. Wraz z ich pogorszeniem następuje podniesienie poziomu wyczerpania emocjonalnego.

Wnioski. Czynnikami chroniącymi strażaków przed

Adres do korespondencji: Agata Madej, Instytut Medycyny Wsi, Lublin, Jaczewskiego 2, 20-090, Lublin, Polska

E-mail: madej_agata@interia.pl

Nadesłano: 25.09.2019; Zaakceptowana do druku: 27.12.2019; Publikacja on line: 31.01.2020 wypaleniem zawodowym są współpraca z przełożonym/ współpracownikami, posiadanie hobby, wysokość uzyskiwanego wynagrodzenia oraz stopień zadowolenia z wykonywanej pracy. Ważne jest również zwiększenie świadomości strażaków odnośnie do możliwości korzystania z pomocy psychologicznej.

\section{Słowa kluczowe}

psychologia pracy, wypalenie zawodowe, funkcjonariusze straży pożarnej, służby mundurowe, zdrowie publiczne

\section{Abstract}

Introduction. The work of firemen is characterised by many dangers. These include actions that may often have a negative impact on health and even life. Frequent exposure to emotionally encumbering events can lead, among others, to symptoms of professional burnout.

Objective. The aim of the study is to present the relationship between personality traits, self-efficacy, stress level and the components of occupational burnout in a group of firemen from the Lublin Province.

Materials and Method. The study involved 120 firemen aged 22-52, working in Biłgoraj and Zamość. The research tools were: an authorial socio-demographic survey, the General Self-Efficacy Scale (GSES), Perceived Stress Scale (PSS-10), NEOFFI Personality Inventory, and the Maslach Burnout Inventory (MBI).

Results. Self-research analyses confirmed the existence of a link between personality traits, levels of stress, self-esteem and components of burnout in a group of surveyed firemen. The increase in the level of conscientiousness determined the increase in the sense of personal accomplishments. Stress reached statistical significance as a predictor of emotional exhaustion and depersonalization. With the improvement of the financial situation and the quality of cooperation between the respondents and their superiors/colleagues, there is a growing sense of self-effectiveness and the level of personal accomplishments. As they deteriorate, emotional exhaustion increases. 
Conclusions. The factors protecting firemen against professional burnout include cooperation with the supervisor/ co-workers, shift work system, level of satisfaction with the performance of work, and the amount of remuneration received. An important factor is also an increase in awareness of firemen concerning the possibility of using psychological assistance in difficult situations.

\section{Key words}

work psychology - professional burnout - firefighters -uniformed services - public health

\section{WPROWADZENIE}

Z uwagi na specyfikę wykonywanego zawodu służby mundurowe należą do grup zawodowych szczególnie narażonych na wypalenie zawodowe. Amerykański portal CareerCast.com podaje, iż w grupie najbardziej stresujących zawodów w 2018 roku wymienia się funkcjonariuszy straży pożarnej [1].

Zawód strażaka ma charakter misji społecznej. Wiąże się z wieloma zagrożeniami, występującymi podczas akcji ratowniczo-gaśniczych, które mogą w sposób negatywny wpływać na zdrowie, a w skrajnych przypadkach - zagrażać życiu [2]. Funkcjonariusze straży pożarnej niejednokrotnie wykonują swoją pracę w sytuacjach wymagających odpowiedzialności oraz szybkiej reakcji $[3,4]$. Praca ta wymaga umiejętności współdziałania w zespole, podporządkowania się rozkazom przełożonego oraz wysokiego poziomu kondycji psychofizycznej. Strażacy funkcjonują w stanie ciągłego napięcia w oczekiwaniu na sygnał alarmu, w gotowości do podjęcia działań ratowniczych $[5,6]$.

Pierwsze objawy wypalenia zawodowego dotyczą głównie wyczerpania emocjonalnego oraz psychofizycznego. Objawia się to m.in. pesymizmem, niechęcią do wykonywania obowiązków zawodowych, zmniejszoną aktywnością własną jednostki, stale utrzymującym się napięciem psychofizycznym. Zdaniem H. Sęk wypalenie zawodowe pojawia się u osób stosujących niekonstruktywne strategie radzenia sobie w sytuacjach stresowych [7]. Według współczesnych badaczy wśród osób najbardziej narażonych na wystąpienie symptomów wypalenia zawodowego są pracownicy zawodów wymagających kontaktów z innymi ludźmi [8]. Jako czynniki warunkujące pojawienie się wypalenia zawodowego wymienia się m.in. oczekiwania, postawy jednostki wobec pracy, cechy organizacyjne oraz osobowościowe [9].

Do wystąpienia objawów wypalenia zawodowego predysponują niektóre cechy osobowości $[10,11]$. Zgodnie $\mathrm{z}$ analizami poprzednich autorów przewiduje się, iż sumienność jest w dodatniej korelacji z poczuciem osiągnięć osobistych. Również można spodziewać się istnienia dodatniego związku pomiędzy neurotycznością a wyczerpaniem emocjonalnym, zaś ujemnego z poczuciem osiągnięć osobistych; ujemnego ekstrawersji z wyczerpaniem emocjonalnym i depersonalizacją oraz dodatniego z poczuciem osiągnięć osobistych [12].

\section{MATERIAŁ I METODY}

Badaniami objęto 120 funkcjonariuszy straży pożarnej, pracujących w służbie czynnej (67 z Komendy Miejskiej Państwowej Straży Pożarnej w Zamościu oraz 53 z Komendy Powiatowej Państwowej Straży Pożarnej w Biłgoraju) w województwie lubelskim w okresie wrzesień-październik 2018 roku. Projekt badań otrzymał zgodę Komisji Bioetycznej Instytutu Medycyny Wsi w Lublinie (nr 5/2018 z dnia 20.09.2018). Ankiety badawcze pozostawiono w pomieszczeniach służbowych.
Zostały one wypełnione przez osoby zainteresowane. W dołączonej informacji funkcjonariusze zostali poinformowani, iż badanie jest anonimowe, zaś otrzymane wyniki posłużą wyłącznie do celów dydaktyczno-naukowych. Załączono również formularz zgody na udział w badaniu.

Wykorzystano następujące narzędzia badawcze: ankietę socjodemograficzną własnego autorstwa, Skalę Uogólnionej Własnej Skuteczności GSES, Skalę Odczuwanego Stresu PSS10, Inwentarz Osobowości NEO-FFI oraz Kwestionariusz Wypalenia Zawodowego Maslach MBI.

\section{Ankieta socjodemograficzna własnego autorstwa}

Ankiet składa się z 22 pytań: 7 pytań stanowi część socjodemograficzną (płeć, wiek, stan cywilny, liczba dzieci, wykształcenie, warunki mieszkaniowe oraz sytuacja finansowa), 11 pytań odnosi się do wykonywanej przez badanego pracy (zawód, staż pracy, godziny nadliczbowe, urlop, stopień zadowolenia z wysokości miesięcznego wynagrodzenia, liczba miejsc pracy, relacje z przełożonym i współpracownikami) oraz 4 pytania dotyczą posiadania hobby, częstości spożywanego alkoholu, palenia papierosów oraz korzystania $\mathrm{z}$ porady psychologa.

\section{Skala Uogólnionej Własnej Skuteczności GSES}

Skala Uogólnionej Własnej Skuteczności GSES w wersji polskiej R. Schwarzera, M. Jerusalema oraz Z. Juczyńskiego mierzy siłę ogólnego przekonania jednostki co do skuteczności własnego radzenia sobie z napotykanymi trudnościami oraz przeszkodami [13]. Im wyższy wynik ogólny, tym wyższy poziom własnej skuteczności osoby badanej, a co za tym idzie - tym silniejsze zaangażowanie jednostki w działanie mimo pojawiających się niepowodzeń. Skala składa się z 10 twierdzeń, którym przyporządkowane są 4 odpowiedzi (nie - 1, raczej nie - 2, raczej tak - 3, tak-4). Suma uzyskanych punktów może mieścić się w przedziale od 10 do 40 pkt. Po przekształceniu na jednostki standaryzowane wyniki w zakresie 1-4 steny traktuje się jako wyniki niskie, 5-6 stenów jako wyniki przeciętne, natomiast 7-10 stenów jako wysokie.

Zgodność wewnętrzną skali GSES oszacowano na podstawie badania 174 osób w wieku 20-55 lat. Współczynnik alfa Cronbacha wynosił 0,85 [13]. Rzetelność oceniana po upływie 5 tygodni metodą test-retest w grupie 85 osób wyniosła 0,78 . Trafność teoretyczną oceniono, prezentując istotne statystycznie zależności miedzy GSES a dyspozycyjnym optymizmem LOT-R (Test Orientacji Życiowej) 0,30 oraz poczuciem własnej wartości RSES (Skala Poczucia Własnej Wartości Rosenberga) - 0,35. Istotna statystycznie zależność istnieje między poczuciem własnej skuteczności a wewnętrznym umiejscowieniem kontroli zdrowia MHLC (Wielowymiarowa Skala Umiejscowienia Kontroli Zdrowia) - 0,25 - oraz nasileniem zachowań zdrowotnych IZZ (Inwentarz Zachowań Zdrowotnych Juczyńskiego) - 0,30 [13]. Zatem wskaźnik poczucia własnej skuteczności jest dobrym wskaźnikiem zachowań zdrowotnych. 


\section{Inwentarz Osobowości NEO-FFI}

Inwentarz Osobowości NEO-FFI autorstwa Costy i McCrae'a, w polskiej adaptacji B. Zawadzkiego i współpracowników. Model osobowości w ujęciu Costy i McCrae’a obejmuje 5 czynników [14]. Są to:

- neurotyczność, która odzwierciedla przystosowanie emocjonalne jednostki vs emocjonalne niezrównoważenie. Jest to podatność na doświadczenie negatywnych emocji (np. gniewu, strachu, niezadowolenia, poczucia winy);

- ekstrawersja, która obrazuje jakość oraz liczbę interakcji społecznych wraz z poziomem aktywności jednostki, jej zdolnością do odczuwania pozytywnych emocji;

- otwartość na doświadczenie - jest to względnie stała oraz ogólna wewnętrzna dyspozycja jednostki do zachowania się w określony sposób. Polega na poszukiwaniu oraz pozytywnym wartościowaniu nabywanych doświadczeń życiowych;

- ugodowość - to cecha odpowiedzialna za poziom nastawienia o charakterze prospołecznym. Jest to umiejętność samodyscypliny oraz kontroli w podążaniu za wyznaczonymi celami;

- sumienność - cecha, która określa stopień zorganizowania jednostki, poziom jej motywacji w działaniach.

Kwestionariusz stanowi 60 twierdzeń samoopisowych. Zadaniem osoby badanej jest określenie prawdziwości każdego twierdzenia w skali od 1 do 5 .

NEO-FFI posiada ogólnie zadowalającą zgodność wewnętrzną, uzyskaną na podstawie współczynnika alfa Cronbacha. Najwyższe współczynniki rzetelności pomiaru odnotowano dla skali sumienności $(0,82)$, neurotyczności $(0,80)$ oraz ekstrawersji $(0,77)$; niższe zaś uzyskano w przypadku skali otwartości $(0,68)$ oraz ugodowości $(0,68)[14]$. Trafność kwestionariusza została wykazana na podstawie analizy wyników badań zależności między wynikami NEO-FFI a ocenami osób badanych dokonywanych przez obserwatorów, odziedziczalnością mierzonych cech oraz ich korelacją z innymi wymiarami temperamentu i osobowością; sprawdzano również trafność czynnikową [14].

\section{Skala Odczuwanego Stresu PSS-10}

Jest to skala autorstwa S. Cohena, T. Kamarcka oraz R. Mermelsteina w polskiej adaptacji Z. Juczyńskiego i N. Ogińskiej-Bulik. Służy ona do oceny poziomu natężenia stresu związanego z własną sytuacją życiową na przestrzeni ostatniego miesiąca. Zawiera 10 pytań, którym przyporządkowano 5 odpowiedzi (nigdy - 0, prawie nigdy - 1, czasem - 2, dość często - 3, bardzo często - 4). Suma uzyskanych punktów mieści się w przedziale $0-40$ pkt. Po przekształceniu na jednostki standaryzowane wyniki w zakresie 1-4 steny traktuje się jako wyniki niskie, 5-6 stenów - jako wyniki przeciętne, natomiast 7-10 stenów jako wysokie. Wynik jest wskaźnikiem oceny własnej sytuacji życiowej jako nieprzewidywalnej, stresującej, nadmiernie obciążającej oraz niepodlegającej kontroli [15].

Rzetelność skali oceniono, szacując jej zgodność wewnętrzną oraz stabilność wewnętrzną. Zgodność wewnętrzną sprawdzono, badając 120-osobową grupę dorosłych, uzyskując wskaźnik alfa Cronbacha 0,86. Rzetelność, która została ustalona na podstawie dwukrotnego badania 30-osobowej grupy studentów w odstępie 2 dni, wyniosła 0,90 , natomiast w odstępie 4 tygodni 0,72 [15]. Trafność kryterialną narzędzia oceniono $\mathrm{w}$ badaniach, które zostały przeprowadzone w latach 2002-2005. Uzyskano wyniki wskazujące na pozytywną korelację PSS-10 z nasileniem stresu zawodowego w pracy (Kwestionariusz do Subiektywnej Oceny Pracy) - głównie między ogólnym wskaźnikiem spostrzeganego stresu a obciążeniem psychicznym $(0,32)$ oraz poczuciem odpowiedzialności $(0,26)$. W badaniach własnych, zrealizowanych wśród losowo dobranych 174 osób dorosłych, korelowano wyniki skali z wynikami COPE (Wielowymiarowy Inwentarz do Pomiaru Radzenia Sobie ze Stresem), SES Rosenberga (Skala Samooceny), GSES (Skala Uogólnionej Własnej Skuteczności) i in. [15]. PSS-10 trafnie mierzy subiektywne odczucia, które wiążą się z problemami oraz zadaniami, sposobami radzenia sobie jednostki.

\section{Kwestionariusz Wypalenia Zawodowego Maslach MBI}

Narzędzie to określa stopień wypalenia zawodowego na 3 płaszczyznach, jakimi są: wyczerpanie emocjonalne (stan przeciążenia psychofizycznego, niechęć do wykonywanej pracy, pesymizm), depersonalizacja (negatywna lub obojętna postawa w stosunku do innych ludzi) oraz osiągnięcia osobiste [16]. Kwestionariusz zawiera 22 twierdzenia, odnoszące się do wykonywanej pracy. Badany ustosunkowuje się do każdego z nich na 6-stopniowej skali (0 - nigdy, 1 - kilka razy w ciągu roku lub rzadziej, 3 - kilka razy w miesiącu, 4 - raz w tygodniu, 5 - kilka razy w tygodniu, 6 - codziennie). Wykorzystano oryginalną wersję kwestionariusza, zakupioną w Amerykańskim Wydawnictwie Psychologicznym Mind Garden.

\section{WYNIKI}

Analizę wyników badań przeprowadzono przy użyciu pakietu IBM SPSS Statistics w wersji 25. Za jego pomocą wykonano analizę podstawowych statystyk opisowych oraz analizy korelacji ze współczynnikiem r-Pearsona i rho-Spearmana, a także linową analizę regresji.

Charakterystykę grupy badawczej z uwzględnieniem cech demograficznych przedstawiono w tab. 1 .

Średni wiek badanych wyniósł 37 lat, zaś średni staż pracy 21 lat. W pierwszym kroku wyliczone zostały podstawowe statystyki opisowe wraz z testem Shapiro-Wilka, badającym normalność rozkładu wszystkich mierzonych zmiennych na skali ilościowej. W grupie strażaków wiek, stres i poczucie własnej skuteczności posiadają rozkład zbliżony do krzywej Gaussa. Dodatkowo cechy osobowości - jedynie poza neurotycznością - również osiągają rozkład zbliżony do rozkładu normalnego. Takie wyniki pozwoliły na dalsze stosowanie testów parametrycznych.

\section{Predyktory wypalenia zawodowego}

W tym etapie wykonano analogiczną serię analiz regresji metodą wprowadzenia dla trzech wymiarów wypalenia zawodowego $\mathrm{w}$ grupie badanych strażaków. W przypadku wyczerpania emocjonalnego model był odpowiednio dopasowany do posiadanych danych: $F(7,108)=5,12 ; p<0,001$; $R^{2}=0,25$. Skorygowane $R^{2}$ wynosi 0,20 , co wskazuje na wyjaśnianie wariancji wyczerpania emocjonalnego przez zaproponowany model w grupie strażaków w 20\%. Jedynie stres osiągnął istotność statystyczną jako predyktor dla wyczerpania emocjonalnego. Jeśli poziom stresu wzrośnie o 1 pkt, natężenie wyczerpania emocjonalnego zwiększy 
Tabela I. Charakterystyka grupy badanych funkcjonariuszy straży pożarnej $(\mathrm{N}=120)$

\begin{tabular}{|c|}
\hline Stan cywilny \\
\hline $\begin{array}{l}\text { - kawaler } 16(13,3 \%) \\
\text { - żonaty } 104(86,7 \%)\end{array}$ \\
\hline Wykształcenie \\
\hline $\begin{array}{l}\text { - zasadnicze } 3(2,5 \%) \\
\text { - średnie zawodowe } 35(29,2 \%) \\
\text { - średnie ogólnokształcące } 23(19,2 \%) \\
\text { - wyższe zawodowe } 32(26,7 \%) \\
\text { - wyższe magisterskie } 23(19,2 \%) \\
\text { - wyższe - tytuł naukowy } 4(3,3 \%)\end{array}$ \\
\hline Warunki mieszkaniowe \\
\hline $\begin{array}{l}\text { - bardzo dobre } 52(43,3 \%) \\
\text { - dobre } 58(48,3 \%) \\
\text { - wystarczające } 10(8,3 \%)\end{array}$ \\
\hline Sytuacja finansowa \\
\hline $\begin{array}{l}\text { - bardzo dobra } 13(10,8 \%) \\
\text { - dobra } 66(55,0 \%) \\
\text { - wystarczająca } 37(30,8 \%) \\
\text { - niewystarczająca } 4(3,3 \%)\end{array}$ \\
\hline
\end{tabular}

\begin{tabular}{|c|}
\hline System pracy \\
\hline $\begin{array}{l}\text { - stały } 12(10 \%) \\
\text { - zmianowy } 108(90 \%)\end{array}$ \\
\hline Korzystanie z godzin nadliczbowych \\
\hline $\begin{array}{l}\text { - tak } 108(90 \%) \\
\text { - nie } 12(10 \%)\end{array}$ \\
\hline Czy badany lubi swoją pracę? \\
\hline $\begin{array}{l}\text { - tak } 119(99,2 \%) \\
\text { - nie } 1(0,8 \%)\end{array}$ \\
\hline Współpraca z kolegami \\
\hline $\begin{array}{l}\text { - bardzo dobra } 47(39,2 \%) \\
\text { - dobra } 66(55 \%) \\
\text { - zadowalająca } 6(5 \%) \\
\text { - niezadowalająca } 1(0,8 \%)\end{array}$ \\
\hline
\end{tabular}

\begin{tabular}{l}
\hline \multicolumn{1}{c}{ Współpraca z przełożonym } \\
- bardzo dobra $36(30 \%)$ \\
- dobra $64(53,3 \%)$ \\
- zadowalająca $13(10,8 \%)$ \\
- niezadowalająca $7(5,8 \%)$ \\
\hline
\end{tabular}

\begin{tabular}{l}
\hline \multicolumn{1}{c}{ Liczba miejsc pracy } \\
\hline - jedno $70(58,3 \%)$ \\
- więcej niż jedno 50(41,7\%) \\
\hline
\end{tabular}

• więcej niż jedno 50(41,7\%)

- bardzo dobra $7(5,8 \%)$

Wysokość wynagrodzenia

- dobra 50(41,7\%)

- zadowalająca 50(41,7\%)

- niezadowalająca 13(10,8\%)

\section{Czy wynagrodzenie wystarcza na zaspokojenie potrzeb?}

- tak 95(79,2\%)

- nie $25(20,8 \%)$

\begin{tabular}{|c|}
\hline Czas na hobby \\
\hline $\begin{array}{l}\text { - } \operatorname{tak} 87(72,5 \%) \\
\text { - nie } 33(27,5 \%)\end{array}$ \\
\hline Palenie papierosów \\
\hline $\begin{array}{l}\text { - tak } 33(27,5 \%) \\
\text { - nie } 87(72,5 \%)\end{array}$ \\
\hline Spożywanie alkoholu \\
\hline $\begin{array}{l}\text { - } \text { kilka razy w tygodniu } 7(5,8 \%) \\
\text { - } \text { kilka razy w miesiącu } 46(38,3 \%) \\
\text { - } \text { okazjonalnie } 63(52,5 \%) \\
\text { - } \text { jestem abstynentem } 4(3,3 \%)\end{array}$ \\
\hline
\end{tabular}

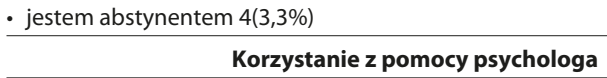

- $\operatorname{tak} 6(5 \%)$

- nie $114(95 \%)$ się o 0,07. Osobowość badanych, jak i ich poczucie własnej skuteczności nie przewidują istotnie tej zmiennej zależnej. Wyniki analiz regresji przedstawiono w tab. 2.

Tabela 2. Analiza regresji dla wyczerpania emocjonalnego w grupie strażaków

\begin{tabular}{|c|c|c|c|c|c|c|c|}
\hline & B & $S E$ & Beta & $t$ & $p$ & skorygowane $R^{2}$ & $F$ \\
\hline (Stała) & 4,49 & 2,11 & & 2,13 & 0,036 & \multirow{8}{*}{0,20} & \multirow{8}{*}{5,12} \\
\hline Neurotyczność & $-0,02$ & 0,02 & $-0,11$ & $-0,81$ & 0,418 & & \\
\hline Ekstrawersja & $-0,02$ & 0,02 & $-0,11$ & $-0,94$ & 0,349 & & \\
\hline $\begin{array}{l}\text { Otwartość na } \\
\text { doświadczenia }\end{array}$ & $-0,04$ & 0,03 & $-0,14$ & $-1,58$ & 0,116 & & \\
\hline Ugodowość & $-0,04$ & 0,03 & $-0,17$ & $-1,49$ & 0,138 & & \\
\hline Sumienność & 0,00 & 0,02 & 0,02 & 0,13 & 0,897 & & \\
\hline Stres & 0,07 & 0,02 & 0,38 & 3,06 & 0,003 & & \\
\hline $\begin{array}{l}\text { Poczucie własnej } \\
\text { skuteczności }\end{array}$ & 0,01 & 0,03 & 0,04 & 0,37 & 0,711 & & \\
\hline
\end{tabular}

Wykonana analiza regresji w grupie strażaków dla poczucia dokonań osobistych również wykazuje istotność statystyczną modelu: $F(7,110)=3,60 ; p=0,002 ; R^{2}=0,19$. Wartości skorygowanego $R^{2}$ wykazują, że model ten przewiduje 14-proc. zmienność poczucia dokonań osobistych w tej grupie. Jak się okazuje, sumienność jest istotnym predyktorem. Jeśli wartość sumienności wzrośnie o 1 , to poczucie dokonań osobistych będzie rosło o 0,08. Neurotyczność, ekstrawersja, otwartość na doświadczenia i ugodowość, a także stres oraz poczucie własnej skuteczności nie osiągnęły istotności statystycznej jako predyktory. Omawiane wyniki zaprezentowano w tab. 3.

Tabela 3. Analiza regresji dla poczucia dokonań osobistych w grupie strażaków

\begin{tabular}{|c|c|c|c|c|c|c|c|}
\hline & B & $S E$ & Beta & $t$ & $p$ & skorygowane $R^{2}$ & $F$ \\
\hline (Stała) & $-2,42$ & 2,94 & & $-0,83$ & 0,411 & \multirow{8}{*}{0,14} & \multirow{8}{*}{3,60} \\
\hline Neurotyczność & 0,01 & 0,03 & 0,05 & 0,36 & 0,723 & & \\
\hline Ekstrawersja & $-0,02$ & 0,03 & $-0,08$ & $-0,69$ & 0,491 & & \\
\hline $\begin{array}{l}\text { Otwartość na } \\
\text { doświadczenia }\end{array}$ & 0,00 & 0,04 & $-0,01$ & $-0,09$ & 0,925 & & \\
\hline Ugodowość & 0,05 & 0,04 & 0,16 & 1,38 & 0,172 & & \\
\hline Sumienność & 0,08 & 0,03 & 0,34 & 2,44 & 0,016 & & \\
\hline Stres & 0,00 & 0,03 & 0,01 & 0,08 & 0,939 & & \\
\hline $\begin{array}{l}\text { Poczucie własnej } \\
\text { skuteczności }\end{array}$ & 0,05 & 0,04 & 0,13 & 1,24 & 0,219 & & \\
\hline
\end{tabular}

Ostatnim krokiem było wykonanie analizy regresji z depersonalizacją jako zmienną zależną w grupie strażaków. Jej wartości wskazują na odpowiednie dopasowanie modelu: $F(7,108)=2,98 ; p=0,007 ; R^{2}=0,16$. Skorygowane $R^{2}$ wskazuje na wyjaśnianie 11-proc. wariancji zmiennej zależnej. Osobowość i poczucie własnej skuteczności nie przewidują istotnej zmiany wartości depersonalizacji w grupie strażaków. Jednak stres jest istotnym statystycznie predyktorem. Wraz ze wzrostem wartości stresu o 1 nasilenie depersonalizacji badanych wzrośnie o 0,06. Wartości poszczególnych współczynników zaprezentowano w tab. 4. 
Tabela 4. Analiza regresji dla depersonalizacji w grupie strażaków

\begin{tabular}{|c|c|c|c|c|c|c|c|}
\hline & B & $S E$ & Beta & $t$ & $p$ & skorygowane $R^{2}$ & $F$ \\
\hline (Stała) & 2,97 & 2,04 & & 1,46 & 0,148 & \multirow{8}{*}{0,11} & \multirow{8}{*}{2,98} \\
\hline Neurotyczność & $-0,02$ & 0,02 & $-0,10$ & $-0,74$ & 0,464 & & \\
\hline Ekstrawersja & 0,00 & 0,02 & 0,02 & 0,18 & 0,856 & & \\
\hline $\begin{array}{l}\text { Otwartość na } \\
\text { doświadczenia }\end{array}$ & $-0,02$ & 0,03 & $-0,07$ & $-0,76$ & 0,451 & & \\
\hline Ugodowość & 0,00 & 0,03 & 0,00 & 0,01 & 0,990 & & \\
\hline Sumienność & 0,01 & 0,02 & 0,03 & 0,21 & 0,837 & & \\
\hline Stres & 0,06 & 0,02 & 0,34 & 2,60 & 0,011 & & \\
\hline $\begin{array}{l}\text { Poczucie własnej } \\
\text { skuteczności }\end{array}$ & $-0,04$ & 0,03 & $-0,17$ & $-1,58$ & 0,117 & & \\
\hline
\end{tabular}

\section{Związki pomiędzy warunkami mieszkaniowymi, sytuacją finansową, współpracą z kolegami oraz przełożonymi i wysokością wynagrodzenia a stresem, poczuciem własnej skuteczności i czynnikami wypalenia zawodowego}

W celu sprawdzenia związku pomiędzy ww. zmiennymi wykonano analizy korelacji ze współczynnikiem rho-Spearmana. Okazuje się, iż wraz z gorszą sytuacją finansową oraz współpracą z kolegami/przełożonymi rośnie u badanych natężenie stresu. Im są one lepsze, tym wyższy jest poziom poczucia własnej skuteczności oraz silniejsze poczucie osobistych dokonań. Z kolei wraz z polepszaniem się poziomu współpracy między badanymi a kolegami z pracy odnotowuje się coraz mniejszy poziom depersonalizacji. Wraz z pogorszeniem sytuacji finansowej, współpracy z kolegami/ przełożonymi, a także wraz ze spadkiem wynagrodzenia wzrasta nasilenie wyczerpania emocjonalnego strażaków. Tabela 5 zawiera wyniki analiz korelacji pomiędzy wyżej omawianymi zmiennymi. Są one bardzo niskie.

Tabela 5. Związki korelacji pomiędzy wypaleniem zawodowym a warunkami mieszkaniowymi, sytuacją finansową, współpracą z kolegami oraz z przełożonymi, a także wysokością wynagrodzenia

\begin{tabular}{|c|c|c|c|c|}
\hline & & $\begin{array}{l}\text { wyczerpanie } \\
\text { emocjonalne }\end{array}$ & $\begin{array}{c}\text { poczucie } \\
\text { dokonań } \\
\text { osobistych }\end{array}$ & $\begin{array}{c}\text { depersonali- } \\
\text { zacja }\end{array}$ \\
\hline \multirow{2}{*}{$\begin{array}{l}\text { Warunki } \\
\text { mieszkaniowe }\end{array}$} & rhoSpearmana & $-0,12$ & 0,10 & 0,00 \\
\hline & Istotność & 0,215 & 0,259 & 0,998 \\
\hline \multirow{2}{*}{$\begin{array}{l}\text { Sytuacja } \\
\text { finansowa }\end{array}$} & rhoSpearmana & $-0,24$ & 0,20 & $-0,08$ \\
\hline & Istotność & 0,009 & 0,030 & 0,371 \\
\hline \multirow{2}{*}{$\begin{array}{l}\text { Współpraca } \\
\text { z kolegami }\end{array}$} & rhoSpearmana & $-0,35$ & 0,17 & $-0,22$ \\
\hline & Istotność & $<0,001$ & 0,065 & 0,018 \\
\hline \multirow{2}{*}{$\begin{array}{l}\text { Współpraca } \\
\text { z przełozonymi }\end{array}$} & rhoSpearmana & $-0,31$ & 0,21 & $-0,26$ \\
\hline & Istotność & 0,001 & 0,023 & 0,005 \\
\hline \multirow{2}{*}{$\begin{array}{l}\text { Wysokość } \\
\text { wynagrodzenia }\end{array}$} & rhoSpearmana & $-0,20$ & $-0,01$ & $-0,13$ \\
\hline & Istotność & 0,030 & 0,879 & 0,157 \\
\hline
\end{tabular}

\section{DYSKUSJA}

Analizy badań własnych potwierdziły istnienie związku między cechami osobowości, poziomem odczuwanego stresu i poczuciem własnej skuteczności a składowymi wypalenia zawodowego w grupie 120 badanych funkcjonariuszy straży pożarnej z terenu województwa lubelskiego.
Największe znaczenie predykcyjne uzyskanych wyników można przypisać sumienności. Objaśnia ona wyższy poziom osiągnięć osobistych. Wiąże się to $\mathrm{z}$ faktem, iż badanych strażaków cechuje wysoki poziom samodyscypliny, zaangażowanie, skrupulatność w wykonywaniu obowiązków służbowych.

Badania N. Ogińskiej-Bulik i M. Kaflik-Pieróg wskazały istnienie zależności między poziomem odczuwanego stresu a emocjonalnym wyczerpaniem i depersonalizacją [17]. Im wyższy poziom odczuwanego stresu, tym wyższy poziom depersonalizacji oraz wyczerpania emocjonalnego. Z kolei wyczerpanie emocjonalne maleje wraz ze wzrostem przekonania o własnej skuteczności. Podobne rezultaty uzyskano podczas analizy badań własnych. J. Vaulerin i wsp. wskazali na istotną rolę sumienności oraz neurotyzmu. Wyniki ich badań potwierdzają, iż neurotyzm jest pozytywnie skorelowany z wszystkimi wymiarami wypalenia zawodowego w grupie 220 strażaków. Potwierdzono również istnienie związku między sumiennością a poziomem wyczerpania emocjonalnego [18].

S.E. Grundy na podstawie badań do rozprawy doktorskiej ustaliła, iż neurotyczność wpływa na poziom wypalenia zawodowego w grupie 142 strażaków z USA. Zgodnie z uzyskanymi w pracy wynikami neurotyczność wyjaśnia $9 \%$ wariancji depersonalizacji, $21 \%$ wyczerpania emocjonalnego oraz 7\% poczucia osiągnięć osobistych [19]. W opinii greckich badaczy V. Yotsidi i wsp. stopień wypalenia zawodowego strażaków zależy od ich wieku, wykształcenia oraz statusu rodzinnego [20].

Literatura przedmiotu wskazuje również na istotną rolę atmosfery miejsca pracy. Klimat organizacyjny ogranicza proces wypalania się pracowników, klimat wspierający znacznie go obniża, natomiast klimat autorytarny sprzyja jego postępowaniu [7, 21, 22]. Badania własne wskazują istotne znaczenie, jakie ma jakość tejże współpracy. W większości relacje wśród badanych funkcjonariuszy straży pożarnej postrzegane są przez respondentów jako dobre, a nawet bardzo dobre. Dodatkowo J.Y. Huynh i wsp. oraz T.D. Smith i wsp. wskazują na wsparcie ze strony rodziny oraz przyjaciół jako istotnie zmniejszające poziom wypalenia zawodowego [23, 24]. Zmniejszenie obciążenia pracą może również sprzyjać dbaniu o zapewnienie równowagi między pełnieniem obowiązków służbowych a relaksem i oddawaniem się hobby w czasie wolnym [25]. W grupie badanych funkcjonariuszy straży pożarnej nieco ponad połowa deklaruje posiadanie hobby.

Kolejnym czynnikiem mającym negatywny wpływ na jakość pracy strażaka jest system zmianowy. Mianowicie jest to również praca w godzinach nocnych. Jedna zmiana trwa całą dobę, natomiast później następuje obowiązkowe 48 godzin odpoczynku. Taka forma pracy stanowi czynnik obciążający oraz nie jest zgodna z naturalnym dobowym trybem życia człowieka. Nieregularne pory snu oraz spożywania posiłków negatywnie wpływają na kondycję psychofizyczną pracownika [26-30]. Informacje te nie znalazły potwierdzenia w badaniach własnych. Pomimo pracy zmianowej badani strażacy w zdecydowanej większości lubią swoją pracę.

Warto również wspomnieć o konieczności zapewniania poradnictwa oraz udzielania wsparcia psychologicznego strażakom. W marcu 2009 roku Komendant Główny Państwowej Straży Pożarnej wydał decyzję „,w sprawie powołania zespołu roboczego do opracowania założeń do organizacji systemu pomocy psychologicznej w krajowym systemie 
ratowniczo-gaśniczym”, co skutkowało przyjęciem Zasad organizacji i funkcjonowania systemu pomocy psychologicznej w Państwowej Straży Pożarnej [5]. Celem organizacji jest zapewnienie pomocy psychologicznej oraz profilaktyka zdrowia psychicznego. Wśród badanych strażaków jedynie $5 \%$ korzystało z pomocy (w tym jedna osoba przyznała, iż przyczyną korzystania ze wsparcia psychologa była niemożność poradzenia sobie ze śmiercia podwładnego, która nastąpiła podczas akcji ratowniczej). Może to wynikać z lęku przed stygmatyzacją ze strony współpracowników/przełożonych lub z faktu utrudnionej dostępności specjalisty, ponieważ ani w Komendzie w Biłgoraju, ani w Zamościu nie ma zatrudnionego na stałe psychologa. Osoba taka na stałe zatrudniona jest w Komendzie Wojewódzkiej Państwowej Straży Pożarnej w Lublinie i podlegają jej wszystkie komendy $\mathrm{z}$ terenu województwa lubelskiego.

Wnioski B. Basińskiej pochodzące z badań własnych potwierdzają, iż trzy czwarte badanych strażaków jest przekonanych o tym, iż nie mogą liczyć na pomoc psychologiczną [31].

\section{WNIOSKI}

Na podstawie wyników badań własnych ustalono, iż czynnikami chroniącymi strażaków z terenu województwa lubelskiego przed wypaleniem zawodowym są współpraca z przełożonym/współpracownikami, posiadanie hobby, wysokość uzyskiwanego wynagrodzenia, sytuacja finansowa oraz stopień zadowolenia $\mathrm{z}$ wykonywanej pracy.

Wzrost zasobów osobistych (w tym poczucie koherencji, poczucie własnej wartości) jednostki, dbanie o szeroko rozumianą higienę psychiczną oraz nauka skutecznych, konstruktywnych metod radzenia sobie w sytuacjach stresowych pozwolą zmniejszyć ryzyko wystąpienia objawów wypalenia zawodowego w służbach mundurowych. Istotna jest tu również rola przełożonego, który tworzy komfortowe warunki pracy, sprzyjające wzrostowi poziomu satysfakcji podwładnych.

Nie mniej ważne jest również zwiększenie świadomości funkcjonariuszy straży pożarnej odnośnie do możliwości korzystania z pomocy psychologicznej w sytuacji stresowej. Badani strażacy w niewielkim stopniu korzystali z tego rodzaju pomocy (w tym tylko jedna osoba w sytuacji związanej z wydarzeniem zaistniałym w czasie pracy).

Praca uaktualnia wyniki badań, które w podobnym zakresie przeprowadzone zostały w 2003 roku przez N. Ogińską-Bulik i M. Kaflik-Pieróg.

\section{PIŚMIENNICTWO}

1. The Most Stressful Jobs of 2018, https://www.careercast.com/jobs -rated/2018-most-stressful-jobs (dostep: 15.07.2019).

2. Woszczyk S, Domagalski J, Żelazko A, Nowak P. Stres i sposoby radzenia sobie z nim przez policjantów i strażaków. Bezpieczeństwo Pracy. 2016; 10: 11-14.

3. Oleksy J. Narażenie zawodowe pracowników straży pożarnej - ryzyko zaburzeń psychofizycznych. Psychologia. 2015; 4 (54): 52-57.

4. Najder A. Wysłużeni - wypalenie zawodowe w pracy strażaka. W Akcji. 2017; 2: 65-69.

5. Weiman M, Przybylski K. Identyfikacja zagrożeń na stanowiskach pracy strażaków zawodowych. Zeszyty Naukowe Politechniki Poznańskiej, Organizacja i Zarządzanie. 2013; 59: 69-84.
6. Oskwarek PP, Tokarska-Rodak M. Stres w środowisku pracy strażaków. Rozprawy Społeczne. 2017; 11(2): 57-61.

7. Mańkowska B. Wypalenie zawodowe. Dylematy wokół istoty zjawiska oraz jego pomiaru. Polskie Forum Psychologiczne. 2018; 23(2): 430-445.

8. Maslach C. Wypalenie w perspektywie wielowymiarowej. W: H Sęk (red.). Wypalenie zawodowe. Przyczyny, mechanizmy, zapobieganie. Warszawa: PWN; 2000: 13-31.

9. Bańkowska A. Syndrom wypalenia zawodowego - symptomy i czynniki ryzyka. Pielegniarstwo Polskie. 2016; 2(60): 256-260.

10. Edler J. A meta-analytic investigation of occupational stress and related organisational factors: is nursing really a uniquely stressful profession? [Dysertacja] Toowoomba: University of Southern Queensland; 2004.

11. Hochwälder J. An empirical exploration of the effect of personality on general and job-related mental ill health. Social Behaviour and Personality: An International Journal 2006; 34(9): 1051-1070.

12. Jędryszek-Geisler A, Izdebski P. Osobowość nauczyciela a wypalenie zawodowe. Edukacja. 2018, 1(144): 106-117.

13. Juczyński Z. Narzędzia pomiaru w promocji i psychologii zdrowia, Warszawa: Pracownia Testów Psychologicznych Polskiego Towarzystwa Psychologicznego; 2012: 89-94.

14.Zawadzki B, Strelau J, Szczepaniak P, Śliwińska M. Inwentarz Osobowości NEO-FFI Costy i McCrae, Warszawa: Pracownia Testów Psychologicznych Polskiego Towarzystwa Psychologicznego; 1998.

15. Juczyński Z, Ogińska-Bulik N. Narzędzia pomiaru stresu i radzenia sobie ze stresem, Warszawa: Pracownia Testów Psychologicznych Polskiego Towarzystwa Psychologicznego; 2012: 11-22.

16. Maslach Ch, Jackson SE, Leiter MP. Maslach Burnout Inventory. Third Edition. Mind Garden. 2016: 19-26.

17. Katsavouni F, Bebetsos E, Malliou P, Beneka A. The relationship between burnout, PTSD symptoms and injuries in firefighters. Occupational Medicine. 2016; 66: 32-37.

18. Ogińska-Bulik N, Kaflik-Pieróg M. Stres w pracy, poczucie własnej skuteczności a zespół wypalenia zawodowego u strażaków. Acta Universitatis Lodziensis. 2003; 7: 37-47.

19. Vaulerin J, Colson SS, Emile M, Scoffer-Mériaux S, d'Arripe-Longueville F. The Big Five Personality Traits and French Firefighter Burnout. Journal of Occupational and Environmental Medicine. 2016; 58(4): 128-132.

20. Grundy SE. Perceived work-related stressors, personality, and degree of burnout in firefighters. Dissertation, 2000.

21. Yotsidi V, Kourmousi N, Dermitzaki E, Pezirkianidis C, Kounenou K. "Add Flow to the Fire": Flow and Hope as a Shield against Burnout of Fire Service Workers. Psych. 2018; 9(6): 1291-1305.

22. Ângelo RP, Chambel MJ. The Reciprocal Relationship Between Work Characteristics and Employee Burnout and Engagement: A Longitudinal Study of Firefighters. Stress \& Health. 2013.

23. Jacobsson A, Backteman-Erlandson S, Padyab M, Egan Sjölander A. Burnout and association with psychosocial work environment among Swedish firefighters; Global Journal of Health Science. 2017; 9(5): 214-225.

24. Huynh JY, Xanthopoulou D, Winefield AH. Social support moderates the impact of demands on burnout and organizational connectedness: a two-wave study of volunteer firefighters. J Occup Health Psychol. 2013; 18(1): 9-15.

25. Smith TD, Hughes K, DeJoy D, Dyal MA. Assessment of relationships between work stress, work-family conflict, burnout and firefighter safety behaviour outcomes. Safety Science. 2018; 103: 287-292.

26. Erenkfeit K, Dudzińska L, Indyk A. Wpływ środowiska pracy na powstanie wypalenia zawodowego. Medycyna Środowiskowa. 2012; 15(3): $121-128$.

27. Wejman M, Przybylski K. Identyfikacja zagrożeń na stanowiskach pracy strażaków zawodowych. Zeszyty Naukowe Politechniki Poznańskiej. 2013; 59: 70-84.

28. Murphy SA, Beaton RD, Pike KC, Cain KC. Firefighters and Paramedics. Years of service, job aspirations, and burnout. AAOHN Journal. 1994; 42(11): 534-540.

29. Bajor T, Krakowiak M. Czynniki psychospołeczne a ocena ryzyka zawodowego w pracy strażaka. Prace Naukowe Akademii im. Jana Długosza w Częstochowie. 2016; 4: 25-32.

30. Caputo L, Hawkes AP, Gosche EE, Vellman PW, Lange NR, Salottolo KM, Coniglio R, Mains CW. The impact of changing work schedules on American firefighters' sleep patterns and well-being. Signa Vitae. 2015; 10(1): 25-37.

31. Basińska B. Postawy strażaków wobec pomocy psychologicznej. W: K Popiołek, A Basińska (red.), Kryzysy, katastrofy, kataklizmy w kontekście narastania zagrożeń. Seria książkowa Czasopisma Psychologicznego. Poznań: Stowarzyszenie Psychologia i Architektura; 2007. 